\title{
AUTOMATION OF THE CALIBRATION PROCESS AS ONE OF THE DIRECTIONS OF DEVELOPMENT OF MILITARY METROLOGY
}

\section{Maciej Klebba $\mathbb{D}$}

1st Military Centre of Metrology, Władysława Miegonia 45 Str., 81-103 Gdynia, Poland; e-mail: klebba5@interia.pl; ORCID ID 0000-0003-1099-577X

\begin{abstract}
The article discussed aim to introduce readers to the problem matter in connection with the changes taking place within the area related to the issue of metrology in the Armed Forces of the Polish Republic. The article depicts the current situation along with the changes, which took place over the recent years, in the structures of Military Metrology, and it presents the major directions of its development, with particular emphasis on the automation of the calibration process.
\end{abstract}

Key words:

automation, metrology, technological development, management system.

Research article

(C) 2019 Maciej Klebba This is an open access article licensed under the Creative Commons Attribution-NonCommercial-NoDerivatives 4.0 license (http://creativecommons.org/licenses/by-nc-nd/4.0/) 


\section{INTRODUCTION}

At the time of very dynamic technological development, as is taking place currently, the handling of military armament and equipment constitutes vast and complicated issue. One of the key elements ensuring appropriate exploitation of equipment is measurement and monitoring of the crucial parameters. Military Metrology is closely related to a given type of armament being used by the Armed Forces of the Polish Republic. As an institution, its task is to ensure appropriate functioning of military technology used by the Armed Forces. The changes taking place in all areas of technology all the more rapidly enforce continuous changes also in the structure of Military Metrology. The major directions of development can be described as:

- quantitative;

- qualitative;

- technological.

\section{QUANTITATIVE DEVELOPMENT}

Together with the technological development of armaments, there is also being recorded the growth in the quantity of measuring devices used. From year to year, we observe increased importance of appropriate measurements. During the times of great geographical explorations, the sailing ships, which were capable of reaching practically just any place there is on earth, in order to function intact, required just the compass, sextant, and possibly, a few other simple measuring devices. Nowadays, even small sailing units of the Navy are equipped with several hundred measuring devices. In order to make possible the management of such enormous quantity of data, there are being implemented integrated measuring systems. These systems are there to collect the data from the sensors scattered around the entire ship and to make it available, following relevant processing is done, in information centres. Changes in the quantity of devices being used in the military units over the recent years can be featured on the example of the devices calibrated by the 1st Military Centre of Metrology (fig. 1). 


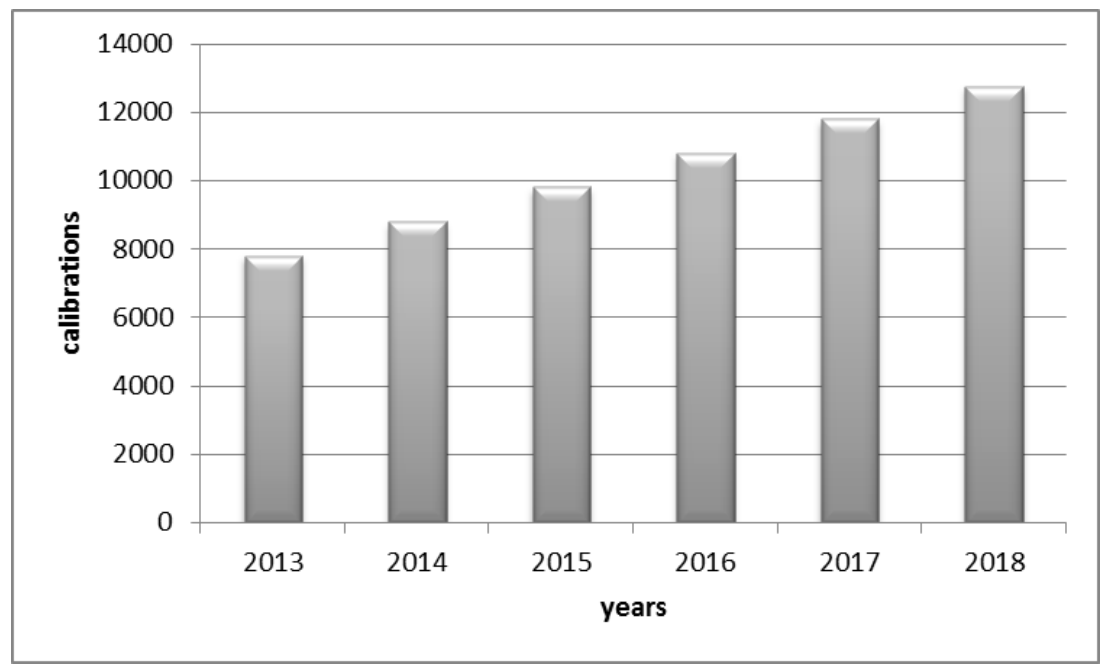

Fig. 1. List of calibrations performed in the 1st Military Centre of Metrology in the years 2013-2018

As can be seen from the presented diagram, the quantity of measuring devices subject to metrological handling is constantly growing. In the coming years, this tendency most probably shall either be preserved or on a rise. In order to meet these challenges, Military Metrology takes steps in order to increase its capabilities and to increase its operation efficiency. Increased efficiency can be achieved through increased staff numbers. Second element of this equation constitutes increased operation efficiency. In most cases, the calibration of a device is about making comparisons of indications of device undergoing verification with the indications of template. These indications are compared and verified by a qualified technician. The method of increasing operation efficiency is the implementation of automated measurements. Currently, in the Centres of Metrology, there are already in operation automated measurement systems. As an example, may serve here the calibration with the use of MET/Cal software. The application of this software in conjunction with appropriate equipment enables for performing calibration in either semi-automated form or completely automated form.

The fig. 2 shows the system for semi-automatic calibration of multimeter with the aid of calibrator. Person doing the calibration according to a specific procedure just follows the commands displayed on the monitor screen. He or she puts down the results of the measurement, changes the settings of device and cable connections. The determination of measurement points and the operation of the standard is done automatically, through the programme. In this case, there is no need for 
making calculations and for determination, whether the admissible error condition is fulfilled. A real enhancement of efficiency resulting from the introduction of semi-automatic procedures of measurements depends on a given type of operated instrument. In case of digital multimeters, the time of calibration has been reduced fourfold from eight hours to just two hours.

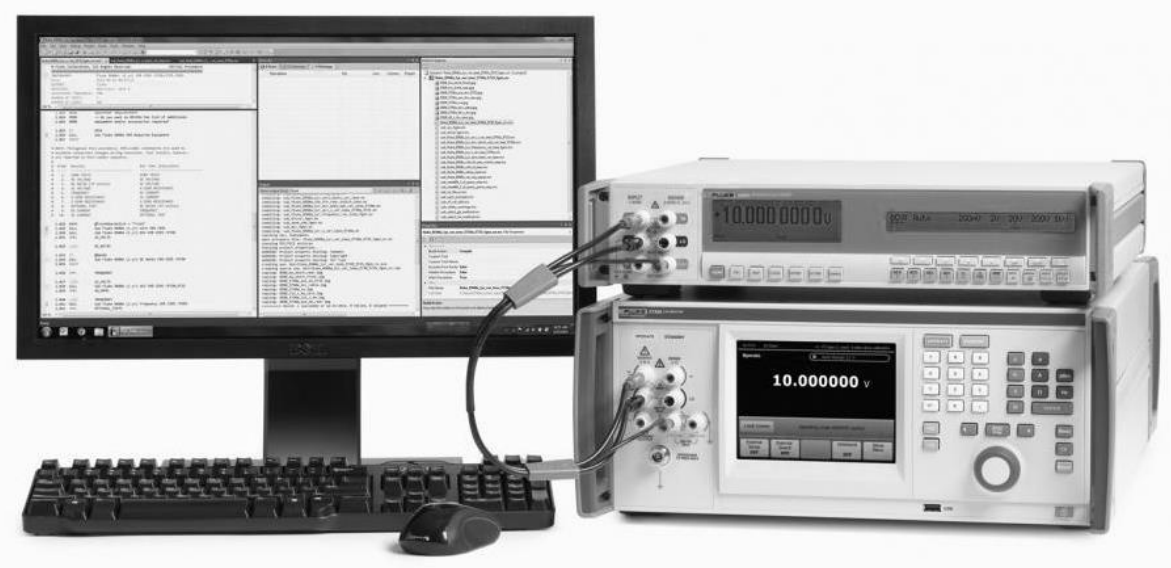

Fig. 2. Set for performing semi-automated calibration

Yet another step is the implementation of fully-automated calibration. The fig. 3 . features the system for automatic calibration of multimeter with the use of calibrator making use of cable connections switch. In this case, the prerequisite is the option of remote control of calibrator, multimeter undergoing verification, and cable switch. MET/CAL software, through its commands, controls all elements of the system, saves and analyses the results of all measurements. Technician is needed just for making the initial connection of the system, and for starting off the entire procedure. Calibration with the use of automatic procedure also lasts for two hours, however a single qualified employee can operate two sets, which substantially increases efficiency. Currently, in Military Metrology the greatest use is made of the following software: MET/CAL and CalPro, as well as own software applications devised for the needs of specific measurement systems.

From year to year, the number of measuring instruments undergoing metrological control using automatic or semi-automatic measuring systems is constantly increasing. This phenomenon can be observed on the example of data from the 1st Military Center of Metrology. In 2004, the first procedures using the MET/CAL software were created. Currently, 1170 different types of electric measuring instruments are calibrated in the Center. Almost half of them are supported in automatic or semiautomatic systems. 


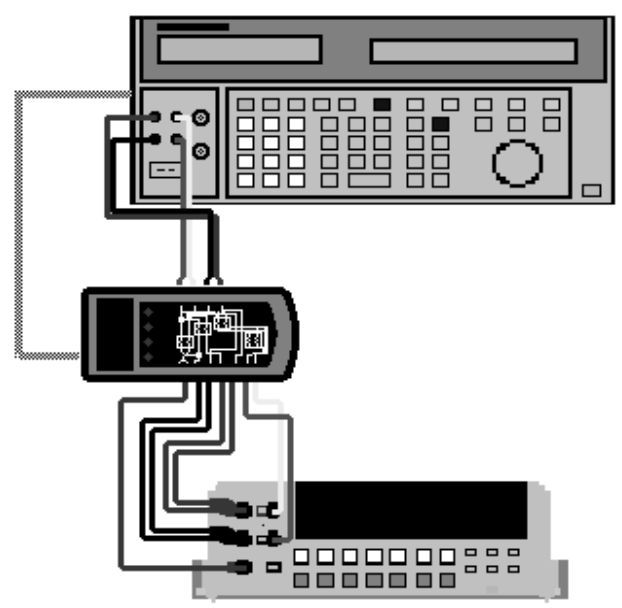

Fig. 3. Set for performing automated calibration

Over the last fifteen years, automated measuring procedures for 519 types of electrical measuring devices have been developed, which accounts for $44 \%$ of all types of instruments serviced in 1st Military Center of Metrology. Due to the simplification of the calibration process and a significant reduction in the time of its execution, work on the development of further methods and procedures continues.

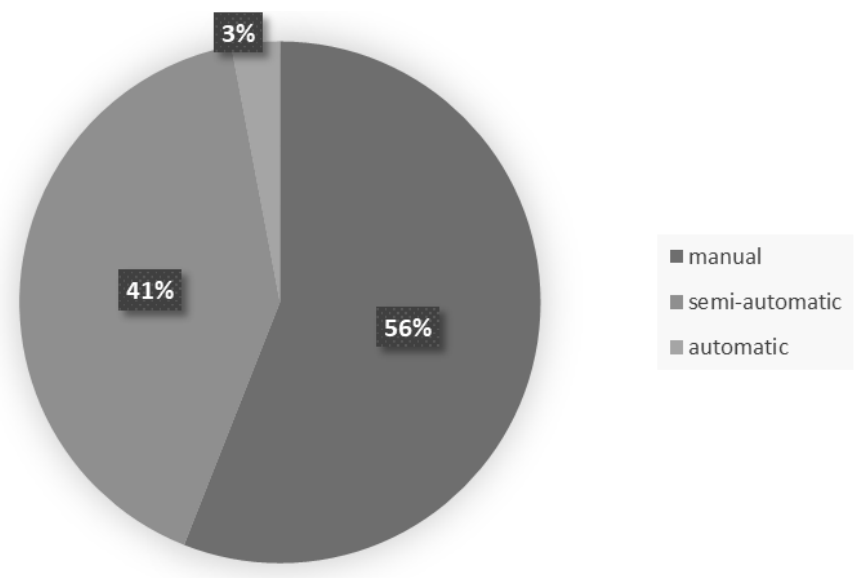

Fig. 4. Percentage set of measurement procedures used in 1st Military Center of Metrology

Not all instruments are suitable for use in automated systems. This is due to both technical reasons and the lack of profitability of using such methods. The graph (fig. 5) shows which basic instrument groups have been included in the automation. 


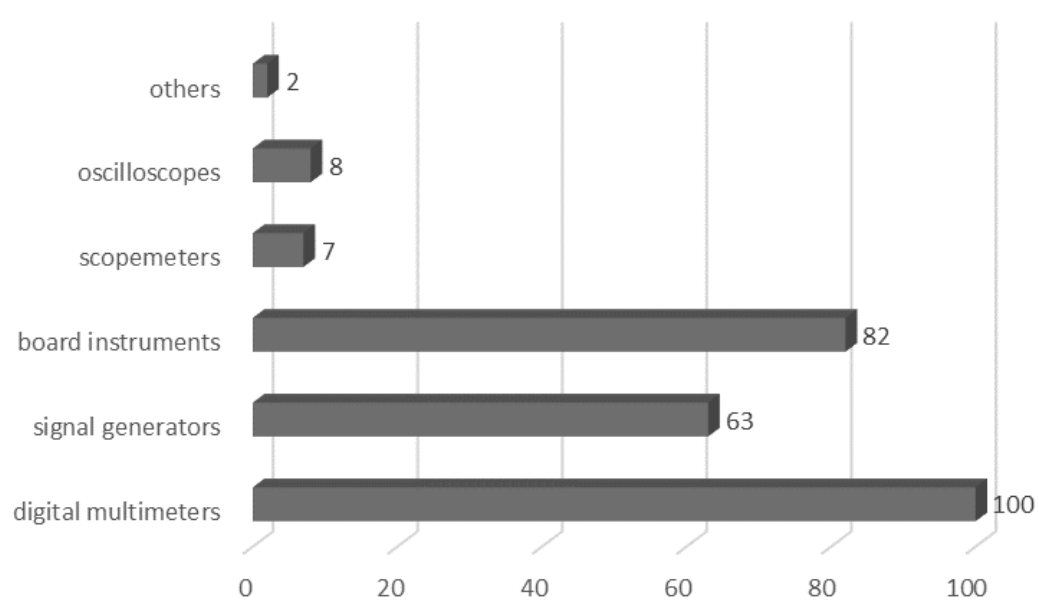

Fig. 5. The percentage of instruments in automated calibration systems

As you can see in fig. 5. In some groups of instruments, such as e.g. digital multimeters, automation is performed for practically every instrument. Currently, work is underway on new methods that allow both to improve the efficiency of current solutions and to enable the extension of automation to further groups of instruments.

Also, do not forget about the quality of the obtained measurement results. Shortening the calibration time should not lead to an increase in their uncertainty. In order to check the impact of automation on the repeatability and quality of the results, an experiment was performed involving the calibration of the same digital multimeter in different conditions and comparison of the obtained effects. The object of the research was the FLUKE 8808 multimeter numbered 2636012. Calibration was performed using the automatic procedure PPM-07.10.01-1-2015-1WOM-FLUKE_8808_5520A taking into account individual measurements and a series of five and ten measurements. The second method was manual calibration using a spreadsheet in variants with one measurement and a series of ten measurements. As a result of the experiment absolute errors obtained by all methods were calculated. For $20 \mathrm{~V}$, $200 \mathrm{~V}$ and $1000 \mathrm{~V}$ DC ranges, the results are shown in fig. 6.

As you can see from the graphs during the calibration with different methods, the results obtained are very similar to each other. The value of the measured error is changed by a maximum of $8 \%$ of the limit value. The obtained absolute error values confirm that in the case of the multimeter under investigation, the automation of the calibration process does not adversely affect the quality of the obtained results. 


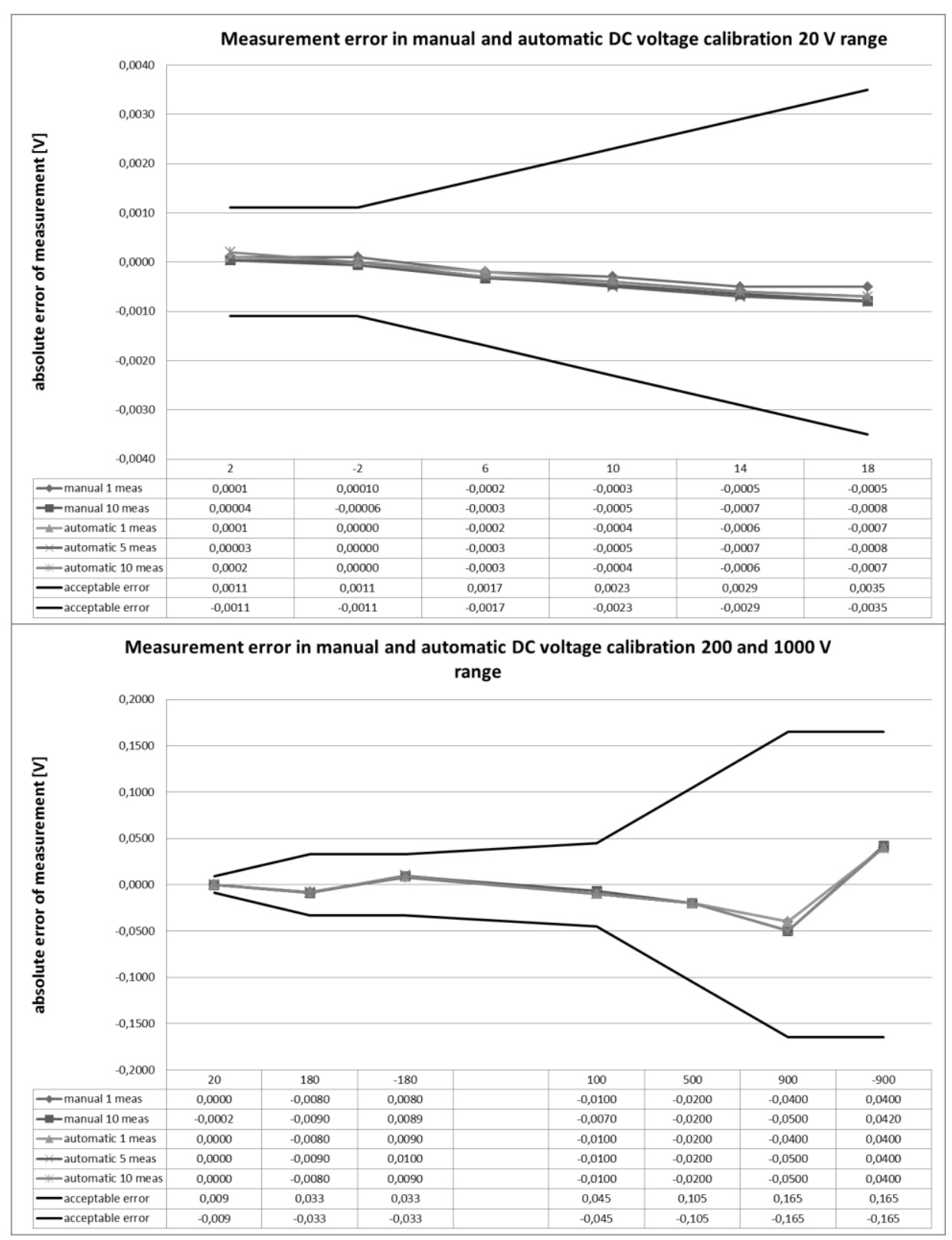

Fig. 6. The results of the experiment of a digital multimeter calibrated by various methods

The quantitative change also constitutes increased quantity of measuring devices operated on the spot at the user's place. In order to increase the quantity of the operated devices and to reduce the time of their stay outside of military unit, 
the devices are calibrated on the spot of their exploitation. For the purpose of performance of these tasks there are used mobile groups of staff and Mobile Metrological Laboratories.

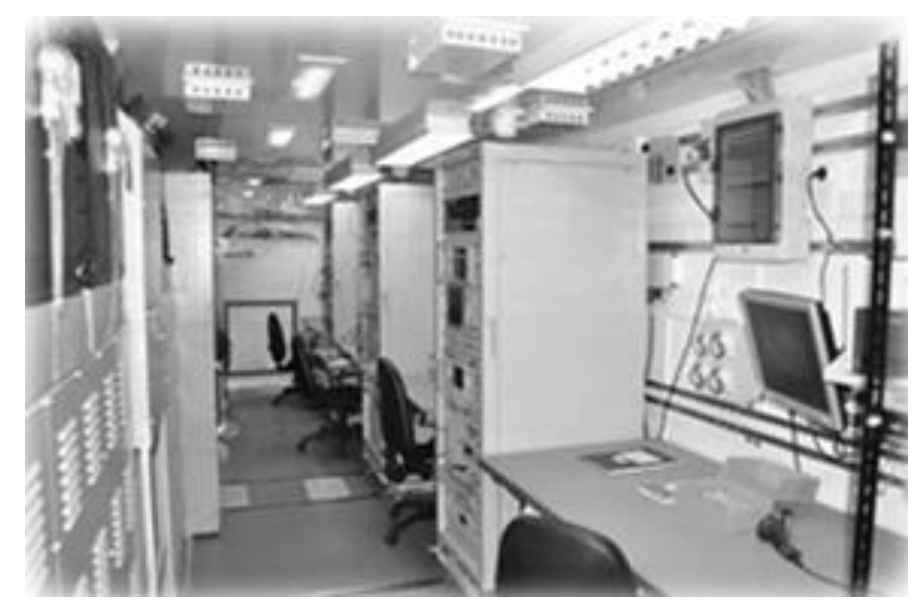

Fig. 7. Mobile Metrological Laboratory inside view

Mobile metrological laboratory RLM TRANSMET is destined for external metrological control of devices and measurement systems of radio-electronic and electric magnitudes, involving pressure and temperature, as well as keys and dynamometric tools in places of their exploitation. It enables for making repairs and adjustments of measuring devices at user's place and the performance of training course in metrological protection [8].

RLM TRANSMET set is formed of a container-type metrological laboratory situated on sub-container semitrailer NS34P made by WIELTON and of a tractor unit with 4-man booth. RLM is constructed on the basis of a standard 40 container. The container houses three compartments: man lock, user compartment, and technical compartment. The user compartment houses four work stands: one repair stand, and three measurement stands (one for verification and calibration of devices, for measuring pressure and temperature or dynamometric tools, as well as two stands for verifying and calibrating radio-electronic devices) [8].

This type of solution enables for arrival directly to military unit and for carrying out the metrological service on the spot in a significantly reduced time. Right now, the Military Metrology commands two mobile laboratories, and the construction of following ones is being planned in the near future. 


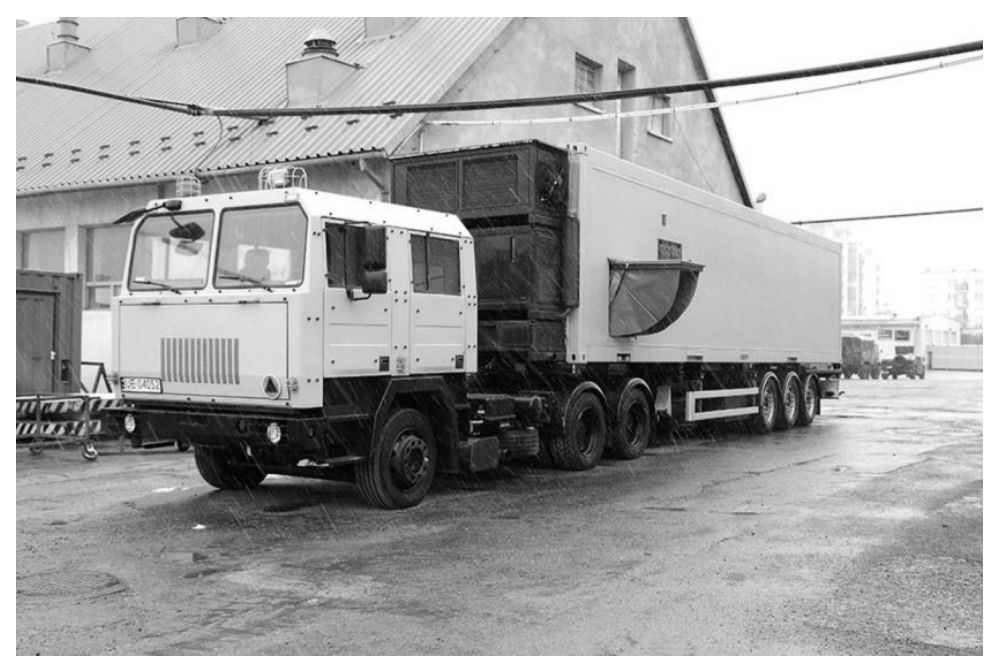

Fig. 8. Mobile Metrological Laboratory

\section{QUALITATIVE DEVELOPMENT}

In order to increase the repeatability and reliability of measurements performed by the Military Centres of Metrology, there have been implemented in them quality management systems. System is based, predominantly, on the provisions of the standard PN/EN ISO/IEC 17025 [7]. As per the decision of the Minister of National Defense, all institutions performing calibration of measuring devices for the Armed Forces of the Polish Republic must hold the certificate of Military Centre of Metrology [2]. As at today, there are six Centres of Metrology and seven metrological laboratories certified. The implementation of management system, most of all, causes enhanced repeatability of performed measurements, and it enables for making comparisons and mutual recognition of results of measurements between the certified institutions. For some types of devices such as, for example, breathalysers, due to legal reasons, military institution certificate proves to be insufficient. Breathalyser, according to the provisions binding currently must be subjected to metrological operation by laboratory holding the accreditation of the Polish Centre of Accreditation or of some other recognized certifying body. To make breathalysers serviceable under the military metrology, 3 WOM in Oleśnica has applied to PCA for accreditation in the scope of analysing breath, which it obtained in the year 2015. 


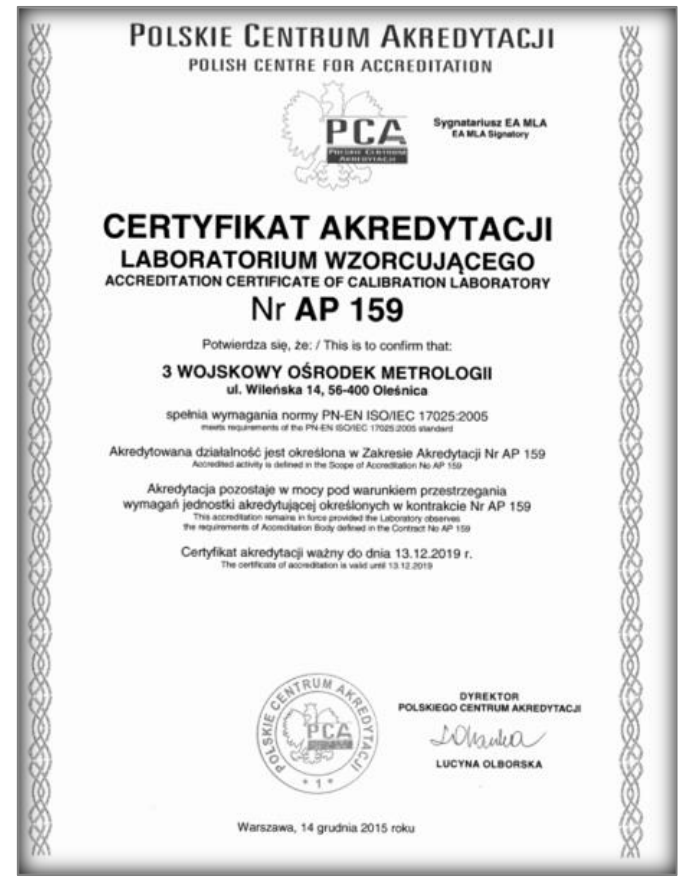

Fig. 9. Certificate 3 of the Military Centre of Metrology issued by the PCA

The systems of quality in all military metrology institutions are continuously developed and perfected. This resulted in the acquisition by all Centres of Metrology of PCA certificates in various areas of measurement. This tendency is maintained and the acquisition of accreditations in following measurement areas is just a matter of time.

\section{TECHNOLOGICAL DEVELOPMENT}

Rapid pace of technological development, which begun at the turn of XIX and $\mathrm{XX}$ century is going on still today. Basic research aroused the interest of metrologists in the early 70s, when it was stated that Josephson's quantum effect, discovered a few years earlier, and based on tunneling of electrons of superconductor through potential barrier, can be applied for constructing incredibly precise and stable model of electric tension [1, 3]. Discovery of quantum Hall effect (QHE) by Klaus von Klitzing in 1980 let for the construction of equally accurate and stable quantum model of resistance (also requiring cryogenic temperatures), which has enhanced the conviction 
of strict relationship of basic research with the practice of metrology at the highest level $[4,5]$. The technology of time measurement developed for the needs of the satellite navigation is currently the subject of implementation in industry, thus constituting one of the priority topics of research carried out under the European Programme of Research in Metrology.

Technological development is best seen on the example of the sources of time and frequency. Generators are used as frequency sources. From the simplest of LC generators through generators with quartz resonators, as far as sources using atom resonators. Right now, there are under way the tests aimed at acquisition of new types of frequency standards and on perfecting the already existing ones. The latest achievements in this area are, among others; caesium fountains, hydrogen masers and optical standards. LC generators are devices of lowest parameters and they have smallish range of applications as frequency standards. A newer solution with much better user parameters are quartz generators. A substantial enhancement of parameters we achieve through additional stabilisation of the frequency of quartz elements. Reduced influence of temperature on the template frequency is realised through the two fundamental technologies. The first one is the compensation by using structures made from resistors, thermistors, and capacity diode. The second one uses digital system containing CA transducer, memory and sensors.

a)

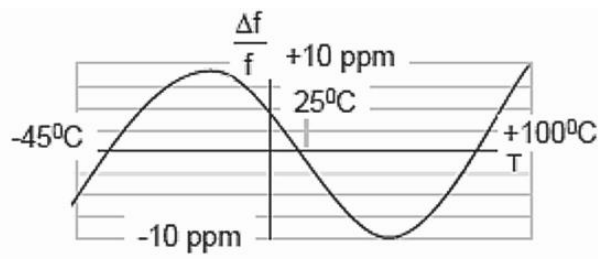

b)

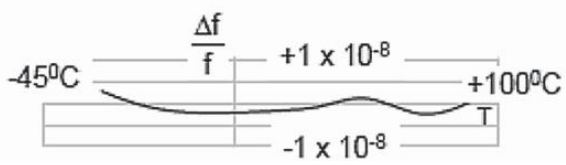

Fig. 10. Comparison of the thermal characteristics of generators of two different types:

a) simple; b) thermostatic

Fig. 10 shows the benefits resulting from the application of various methods of reducing of the influence of the changes of surroundings' temperature on the quartz generators' frequency. Depending on the applied technical solution and range of work temperature for generators with compensation of temperature changes of frequency, we can obtain stability which would be better than the one achieved in simple quartz 
generators from 10 to 20 times, and in thermostatic generators even up to 1000 times [6]. Right now, the OCXO generators achieve daily stability at the level of 5•10-11.

Another solution enhancing the stability of frequency is the application of atom standards. First atom clock was constructed in 1955. It was the crowning of 20-year long time period of research carried out by several scientific laboratories, such as NBL (USA), LPMO (FRA), NPL (GB). Currently, among the main time sources we name:

- rubidium frequency standards;

- methane frequency standards;

- cesium atomic clocks;

- hydrogen masers;

- cesium fountains;

- atomic clocks of the new generation.

Atom clocks constitute currently the most precise sources of time used in the world. The precision of atom standards is nowadays 1-10-12/year. Atom caesium standards are commonly used as sources of standard signals on board of navigation satellites. Significant improvement of exploitation parameters let for enhancement of lifespan of satellite from a dozen or so months to approximately ten years. In the latest versions of satellites, rubidium standards are becoming to be used. Work on development of the standards with ever greater stability has been going on constantly for many years. The token of development can be the comparison of standards used over the years by NIST for creating USA time scale. In 1950, NIST was using the NBS1 standard of the accuracy of 5•10-11, whereas in 2016 the NIST-F2 standard was characterized by the accuracy of $1.5 \cdot 10-16$ in relation to the UTC scale. The standards of new generation in the OCXO area constitute the solution based on sapphire resonators (FEMTO 2017). In the area of standards characterised by highest consistency of frequency tend to prevail the hydrogen masers, caesium fountains, and opto-electric standards. Hydrogen masers are available in mass production, whereas the remaining ones are produced individually.

In the tab. 1, there are featured the various types of frequency templates along with the comparison of their parameters.

As can be seen from the above table, the accuracy (stability) of standards, depending on a given type and on the applied ever more modern solutions, is rising considerably. The development of new technologies and measurement techniques is not solely restricted to frequency measurements. Dynamic development of measurement techniques covers practically every single area of technology and physical quantity. 
Tab. 1. Comparison of parameters of different frequency standards [5]

\begin{tabular}{|l|l|l|}
\hline \multicolumn{1}{|c|}{ Types of frequency standard } & \multicolumn{1}{|c|}{ Accuracy } & \multicolumn{1}{|c|}{ Typical area of applications } \\
\hline Simple quartz oscillators SXO, XO & $1 \mathrm{E}-5-1 \mathrm{E}-4$ & Computer clocks \\
\hline $\begin{array}{l}\text { Temperature Compensated Quartz } \\
\text { Oscillators TCXO, DTCXO }\end{array}$ & $1 \mathrm{E}-6$ & Frequency source in radio devices \\
\hline $\begin{array}{l}\text { Mikkroprocesor Temperature } \\
\text { Compensated Quartz Oscillators } \\
\text { MCXO }\end{array}$ & $1 \mathrm{E}-8-1 \mathrm{E}-7$ & $\begin{array}{l}\text { Clocks in systems with spectrum } \\
\text { scattering }\end{array}$ \\
\hline Ovenized Quartz Oscillators OCXO & $1 \mathrm{E}-8$ & $\begin{array}{l}\text { Navigation systems, frequency } \\
\text { standards, radar systems }\end{array}$ \\
\hline Rubidium atomic standard & $1 \mathrm{E}-9$ & Radar systems, satellite clocks \\
\hline Caesium atomic standard & $1 \mathrm{E}-12-1 \mathrm{E}-11$ & $\begin{array}{l}\text { Frequency standards, satellite } \\
\text { clocks, time scale clock }\end{array}$ \\
\hline Hydrogen maser & $1 \mathrm{E}-14$ & Satellite clocks, time scale clock \\
\hline Cesium Fountain & $1 \mathrm{E}-16$ & Time scale clock \\
\hline
\end{tabular}

\section{CONCLUSIONS}

Changes that are taking place, both, in the Armed Forces of the Polish Republic, and in the contemporary measurement technique determine the necessity of continuous development of Military Metrology. In the article there have been presented the three fundamental directions of development. The quantitative direction is realised in continuous way in every single Centre of Metrology, and in the remaining institutions providing services for the benefit of the Armed Forces of the Polish Republic. The issues in connection with the qualitative development have been initiated by the Military Centre of Metrology and are continuously being implemented. The technological development is determined by the changes occurring in the measurement techniques. In this case, the only solution is to follow on day-to-day basis the changes that occur, both, in military techniques, and in the world's measurement technique.

\section{REFERENCES}

[1] Benz S. P., Hamilton C. A., Application of the Josephson effect to voltage metrology, 'Proc. IEEE', 2004, Vol. 92, pp. 1617-1629.

[2] Decyzja Nr 209/MON Ministra Obrony Narodowej z dnia 12 czerwca 2015 r. w sprawie działalności metrologicznej w resorcie obrony narodowej, Dz. Urz. MON, Warszawa, 15 czerwca 2015, poz. 161 [Decision number 209 the Minister of National Defense about metrological activity in the Ministry of National Defense - available in Polish].

$1(216) 2019$ 
[3] Jeanneret B., Benz S. P., Application of Josephson effect in electrical metrology, 'Eur. Phys. J. Special Topics', 2009, Vol. 172, pp. 181-206.

[4] Jeckelmann B., Jeanneret B., Quantum Hall Effect as an Electrical Resistance Standard, 'Séminarie Poincaré, 2004, Vol. 2, pp. 39-51.

[5] Klitzing K., 25 Years of Quantum Hall Effect (QHE). A Personal View on the Discovery, Phisics and Applications of this Quantum Effect, 'Séminarie Poincaré', 2004, Vol. 2, pp. 1-16.

[6] Masiukiewicz A., Źródła czasu i częstotliwości. Stan aktualny i kierunki rozwoju, 'Kwartalnik Naukowy Uczelni Vistula', 2007, No. 3(53), pp. 130-147 [Sources of time and frequency. Current status and directions of development - available in Polish].

[7] Standard PN-EN ISO/IEC 17025.

[8] Wojskowe Centrum Metrologii [Military Center of Metrology], [online], https://wcm.wp.mil.pl/pl/ [access 28.01.2019].

\section{AUTOMATYZACJA PROCESU KALIBRACJI JAKO JEDEN Z KIERUNKÓW ROZWOJU METROLOGII WOJSKOWE J}

\section{STRESZCZENIE}

Artykuł jest wprowadzeniem w zagadnienia związane z metrologią w Siłach Zbrojnych Rzeczypospolitej Polskiej. Przedstawiono w nim aktualną sytuację metrologii wojskowej wraz ze zmianami, jakie zaszły w ostatnich latach. Zaprezentowano także główne kierunki jej rozwoju, ze szczególnym uwzględnieniem automatyzacji procesu kalibracji.

Słowa kluczowe:

automatyzacja, zabezpieczenie metrologiczne, rozwój technologiczny, system zarządzania.

Article history

Received: $\quad 07.02 .2019$

Reviewed: 25.03.2019

Revised: $\quad 29.03 .2019$

Accepted: $\quad 29.03 .2019$ 